\title{
13 \\ Pottery from the Tomb of Karakhamun (TT 223)
}

\author{
Fulia Budka
}

\begin{abstract}
A first season of recording the pottery from TT 223 was carried out in August 2011. The main aim was to establish dating for the ceramics, and thus, to gain insights into the use-life of the tomb. A first corpus of wares and of pottery types was established. Additional goals were the clarification of the general character of the ceramic material and of possible differences and variations between individual areas and locations within the tomb, and an initial assessment of its functional use. The purpose of this report is to present a preliminary overview of the material (corpus of wares and types) and to highlight aspects of dating and functional use. Since the documentation of the ceramics from TT 223 will hopefully continue in the near future, providing further evidence, a full analysis of the pottery must await the results of this work.
\end{abstract}

\section{The Pottery from TT 223}

\section{Quantitative Data}

Deriving from 229 different find positions, a total of 6,791 sherds were looked at, sorted, and recorded according to their ware and vessel type. Among these sherds, 1,327 were classified as diagnostics during the first stage of work. It soon became clear that within certain areas, such as the burial compartment, the material is highly disturbed, but complete vessels can be reconstructed from the fragments. With the assistance of two workmen, the second and very time-consuming stage of work was to reconstruct the vessels from individual sherds of the same ware and type. This proved to be very successful and, for example, nine storage vessels/jars from the burial compartment (chamber X and shaft), including chamber IX.6, were completely reconstructed (mostly dating from the fifth to third centuries BC, see figure 13.3.2). 
Table 13.1: Location of processed pottery (2011) from TT 223

\begin{tabular}{lr}
\hline Area & Amount \\
\hline I.4 & 621 \\
IV & 1927 \\
V & 190 \\
V.A1 & 1178 \\
V.B1 & 487 \\
VI.2 & 11 \\
VII & 224 \\
IX.1+2, IX.5 & 17 \\
IX.6 & 300 \\
X shaft & 24 \\
X burial chamber & 1781 \\
Other & 31 \\
\hline Total & 6791 \\
\hline
\end{tabular}

The distribution of the processed material according to areas within TT 223 is illustrated in table 13.1.

The majority of the material that was studied derives from the First Pillared Hall (IV), excavated in 2008 and 2009, and from the burial compartment, investigated in 2010 and 2011. The burial chambers V.A1 and V.B1, excavated in 2011, also yielded a substantial volume of material. Two hundred thirty-two pottery vessels were processed in detail, registered and documented by photos, and were recorded in the database in 2011. In addition, drawings of seventy pieces were realized in 2011.

Table 13.2 summarizes the general dating of the vessels registered in 2011.

The peak of the pottery presence in the studied material from TT 223 is clearly the early Ptolemaic period (fourth to third centuries BC), followed by the Kushite and Persian periods (Twenty-fifth and Twenty-seventh Dynasties). This is not unexpected within the Theban necropolis: the reuse of monumental temple tombs flourished, especially during the fourth and third centuries $\mathbf{B C}^{1}{ }^{1}$ a phase when a reduction in the quantity of pottery associated with individual burials is noticeable. ${ }^{2}$ The presence of material from the fifth century вс (Persian period) in TT 223 is remarkable-as yet, this phase is not well understood in Theban funerary archaeology. ${ }^{3}$

In the case of TT 223, the state of preservation of the archaeological material deriving from the subterranean chambers has to be taken into account-its burial compartments have been heavily and repeatedly plundered from antiquity. As a result of this considerable disturbance, the original burials are likely to be much less well preserved than material from the later reuse of the pillared halls. 
Table 13.2: General dating of registered pottery vessels from TT 223, season 2011.

\begin{tabular}{lrc}
\hline Period/dating & Number of vessels & Percentage \\
\hline 25th Dynasty & 35 & 15.1 \\
26th Dynasty & 6 & 2.6 \\
27th Dynasty & 24 & 10.3 \\
5th-3rd centuries BC & 18 & 7.8 \\
Ptolemaic & 109 & 47.0 \\
Roman & 1 & 0.4 \\
Late Roman & 1 & 0.4 \\
Coptic & 1 & 0.4 \\
Islamic & 4 & 1.7 \\
Unclear & 33 & 14.2 \\
\hline Total & 232 & 99.9 \\
\hline
\end{tabular}

\section{Corpus of Wares and Types-General Remarks}

The site-specific categorization of fabrics occurring in TT 223 follows the system developed for the material from the Austrian concession in the Northern Asasif. ${ }^{4}$ Nile silt clay is by far the most common material. The majority of the pottery belongs to a medium, straw-tempered fabric equivalent to Vienna System Nile B2, labeled as Nile B3, and to a coarser variant with chaff, labeled as Nile C3. In addition, variants of these Nile clays occur, characterized by a high concentration of mica and sand, and often having been burnt in a reduced atmosphere (for example, Reg. No. P 2011.26.2) (see fig. 13.5.2). Another variant of Nile clay, which can be compared to Nile D of the Vienna System with some limestone inclusions, is rare but attested for some tall-necked jars (see fig. 13.2.5). ${ }^{5}$ The surface of Nile clay vessels is sometimes left uncoated, is quite regularly red washed, and sometimes is red slipped or white washed. For a particular type of red-slipped jar (see fig. 13.3.2), a clay is attested which can be compared to fabric J1 at Saqqara, being similar to a fine Nile C. ${ }^{6}$ Islamic painted ware, well known from other sites at Thebes, was produced in a coarse Nile or mixed clay, labeled as I-g (see fig. 13.9).?

Marl clays are less common than Nile clays, and the predominant marl clay for the material from TT 223 is Marl A4 in several variants. ${ }^{8}$ It was used both for open and closed forms (beakers, bowls, and storage vessels). The marl clay variant " $\mathrm{K}$ 200" was used for various painted vessels of the Ptolemaic Egyptian 'Hadra ware' and oil jars as is well attested elsewhere in Thebes (see fig. 13.8). ${ }^{9}$ 


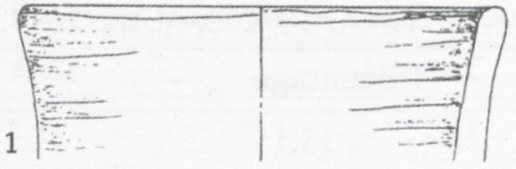

3
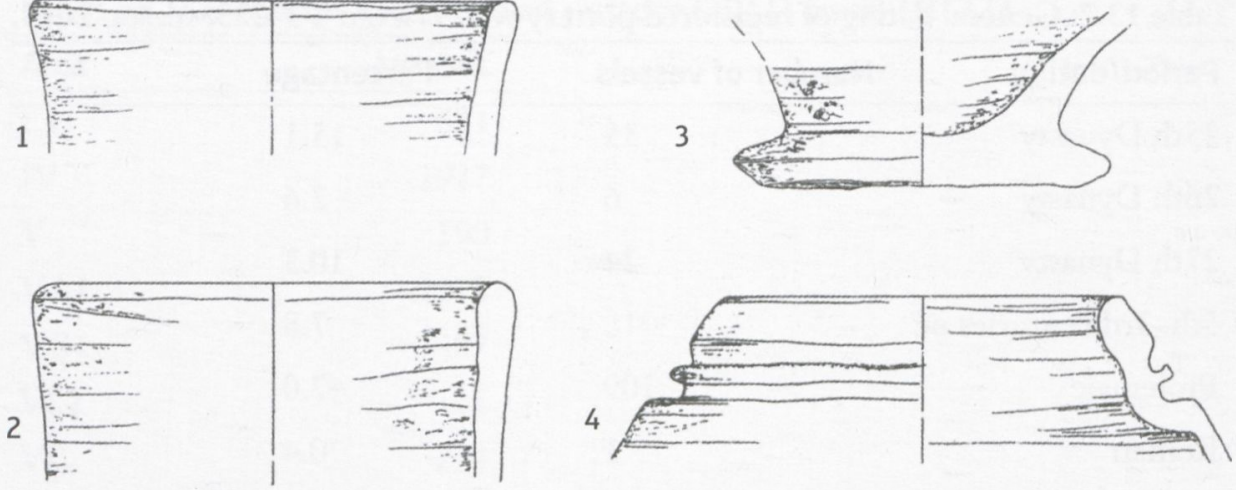

Fig. 13.1. Selected pottery from the burial compartment of TT 223 (Twenty-fifth Dynasty) (scale 1:2). Drawing Julia Budka

A distinctive clay can be identified as Oasis ware and compared to Hope's B23 from Dakhla Oasis; ${ }^{10}$ it is attested by two kegs from TT 223 (fig. 13.2.3). Some imported clays of non-Egyptian provenence are also present within the corpus, namely imported amphorae of Phoenician, Chiotic, and Clazomenian origin of a Twenty-sixth to Twenty-seventh Dynasty date. ${ }^{11}$ In Ptolemaic times, Aegean amphorae were also copied in marl clay (for example, Reg. Nos. P 2011.3.5, 2011.142). ${ }^{12}$

\section{Pottery from the Burial Compartment of TT 223}

The focus in 2011 was the ceramics derived from the main burial areas, including room IX.6, the burial chamber X and its shaft, and the steps toward VII and IX. The volume of pottery excavated in the burial chamber is considerable and the material is quite mixed in character-Late Period pottery (Twenty-fifth to Twenty-seventh and Thirtieth Dynasties) appears together with Ptolemaic, Coptic, and modern ceramics. Typical types of storage vessels and bowls, most likely to have served as containers for grave goods, are present, as well as offering pottery with traces of incense such as common beakers and goblets. ${ }^{13}$

\section{Pottery of the Twenty-fifth Dynasty}

Despite the mixed appearance of the ceramics from area $\mathrm{X}$, a small quantity of Twenty-fifth Dynasty vessels was identified-these very likely formed part of the original burial equipment of Karakhamun. A total of thirteen vessels from the burial compartment date to the Kushite period and comprises the following types: ${ }^{14}$ five conical cups with flat bases (Aston's type 55) (fig. 13.1.3), three round-based beakers (Aston's types 39-40) (cf. figs. 13.5.1 and 13.5.2), two globular jars (Aston's type 59) (figs. 13.1.1 and 13.1.2), and one large sausage jar (Aston's types 124-25), all manufactured in various Nile clay fabrics. The marl clay vessels include a restricted bowl with handles (Aston's type 135) and a typical late eighth- to seventh-century BC storage vessel with grooved rim (Aston's type 159) (fig. 13.1.4). 
Of particular interest within this small pottery corpus are slender beakers with direct rims and round bases (figs. 13.5.1 and 13.5.2) - they are not found among typical Egyptian tomb groups of the Twenty-fifth Dynasty, but find their closest parallels at Medinet $\mathrm{Habu}$, within the ceramics associated with the burial of Amenirdis. ${ }^{15}$ The vessel type is common within Napatan tomb groups in Kush itself, ${ }^{16}$ and a similar example was recovered from a small Kushite family tomb in the Northern Asasif, identified as a Kushite import (tomb VII of the Austrian concession). ${ }^{17}$ It is reasonable to assume that these small beakers from TT 223 are also Kushite imports, attesting to the indigenous tradition of Karakhamun within his Egyptian temple tomb. The red-washed surface of the beakers and their reduced burning support this identification.

\section{Persian Pottery and Possible Remains of an Embalming Cache}

No Saite pottery could be safely identified as coming from the burial compartment of TT 223. However, the Oasis keg Reg. No. P. 2011.1 might be Twenty-sixth Dynasty in date, or a bit later (fig. 13.2.3). In general, for some types, especially storage vessels, a close dating as either Twenty-sixth Dynasty or Twenty-seventh Dynasty is not always possible. ${ }^{18}$ Thus, as yet unclear evidence for any reuse of the main burial compartment in Saite times has to be treated with caution and must await the complete analysis of the funerary material.

The next phase of use clearly traceable after the burial of Karakhamun is attested by a small corpus of vessels which are well known from the contexts of embalming caches, both from Thebes and Saqqara. ${ }^{19}$ The majority of the fragments from which these vessels were reconstructed were found within TT 223 in room IX.6, but several joining pieces were found in the shaft filling and also in the burial chamber. It seems worth speculating that the cache of vessels was originally deposited within IX.6 in the fifth century $\mathrm{BC}$ and consequently disrupted during the later reuse and plundering of the tomb. ${ }^{20}$

The group includes the following: two Chiotic amphorae, one Clazomenian amphora, one Aegean amphora of unknown origin (possibly Eastgreek), two Phoenician amphorae with hieratic dockets, ${ }^{21}$ one Egyptian marl clay storage vessel, and 
two Nile clay vessels (one red-washed slender jar with tall neck and rounded base, and one red-slipped bottle with rolled rim, ribbing on the neck, and round base) (fig. 13.3.2). Whether there have been any open forms as well will be established by a closer analysis in the next season.

It is interesting to note that this embalming cache from TT 223 does not only include imported amphorae from the Aegean and Phoenicia, but also at least one vessel that is commonly associated with the northern manufacture of Egyptian pottery during the Twenty-seventh Dynasty. At present, the complete example of a thin-walled, red-slipped bottle with rolled rim and ribbing on the neck (Reg. No. P 2011.117.1 + 3) is the most southern evidence for this well-known Saqqara type (fig. 13.3.2). ${ }^{22}$

Typical types of open forms for the fifth to fourth centuries BC are also present within the burial compartment: a minimum of three handled dishes ('Henkelschalen,' fig. 13.2.2) and several so-called 'goldfish bowls' were reconstructed (fig. 13.2.1). These find many parallels within the Theban necropolis ${ }^{23}$ and at Karnak. ${ }^{24}$

\section{Pottery of the 30th Dynasty and the Ptolemaic Times}

As is well known from other Late Period temple tombs in Thebes, TT 223 experienced a phase of intense reuse as a burial place in the fourth and third centuries $\mathbf{B C}$
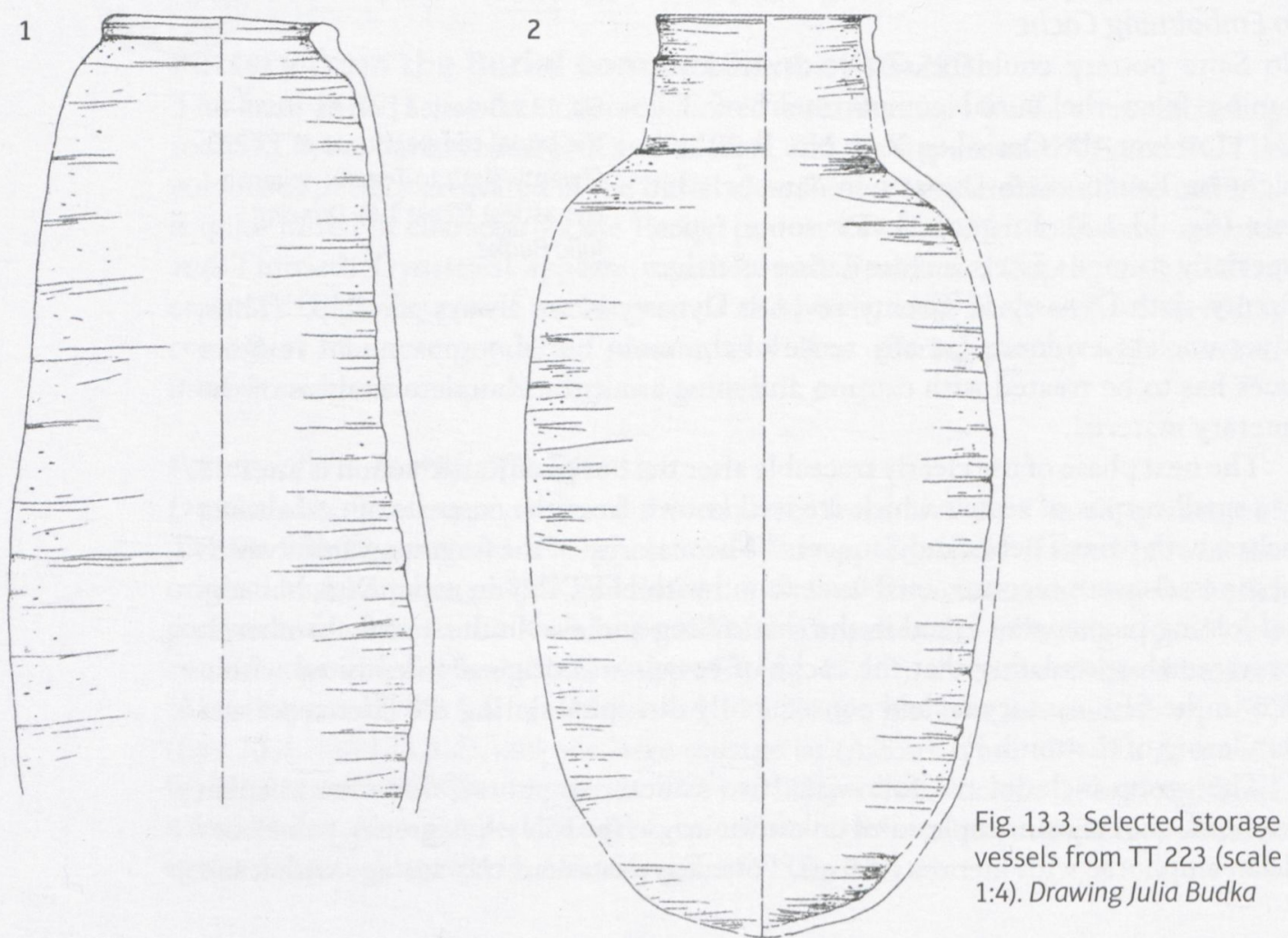
(see above) - this phase has also left traces in the burial compartment. The most common pottery types that find many parallels throughout the Theban necropolis are small conical beakers used as burners (see fig. 13.4.2), ${ }^{25}$ miniature vessels, situla-like vessels, amphorae, pot stands, and painted storage vessels in the Egyptian 'Hadra ware' style (fig. 13.7). ${ }^{26}$

\section{Pottery from Room V and its Shafts}

The material from shafts V.A1 and V.B1 was recorded, but has not yet been analyzed in detail. In both shafts, material of the Twenty-fifth Dynasty was present, as well as Saite and Persian pottery (fig. 13.5). The Kushite ceramics include, again, an imported Napatan beaker (fig. 13.5.2) and some marl clay storage vessels, as well as a fragment of a small bottle in Oasis ware, most likely from Dakhla. ${ }^{27}$ Ceramics from the Thirtieth Dynasty and the early Ptolemaic era are especially abundant in V.A1, including nice pieces of painted Hadra-style ware. This material can be associated with a reuse of the shaft as a burial place in the fourth and third centuries BC.

The amount of material coming from V.B1 was considerably smaller and the date of usage of this shaft is difficult to assess. Pieces from the Twenty-fifth Dynasty are present, as well as vessels from the Twenty-sixth and Twenty-seventh Dynasties and Ptolemaic and Coptic times (various open shapes as well as storage vessels). It can be assumed that chamber V.B1 was repeatedly used as a burial place, at the latest from the Twenty-sixth Dynasty onward. ${ }^{28}$

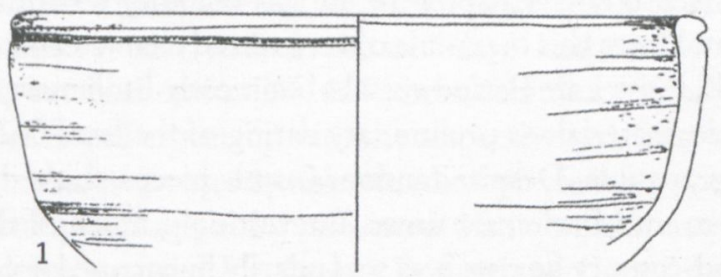

Fig. 13.4. Ptolemaic pottery from the burial compartment of TT 223 (scale 1:2). Drawing

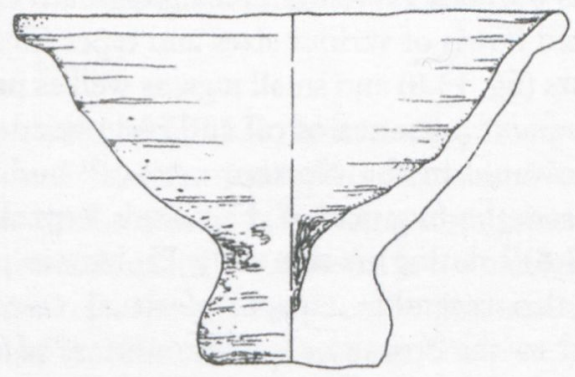
Julia Budka 

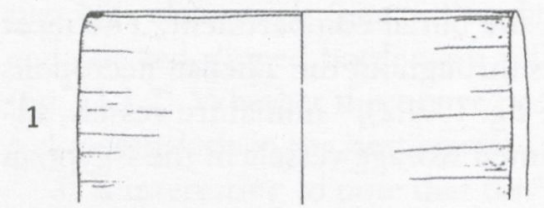

3

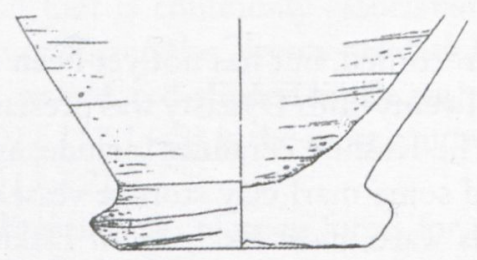

5

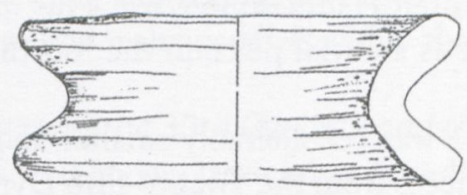

2
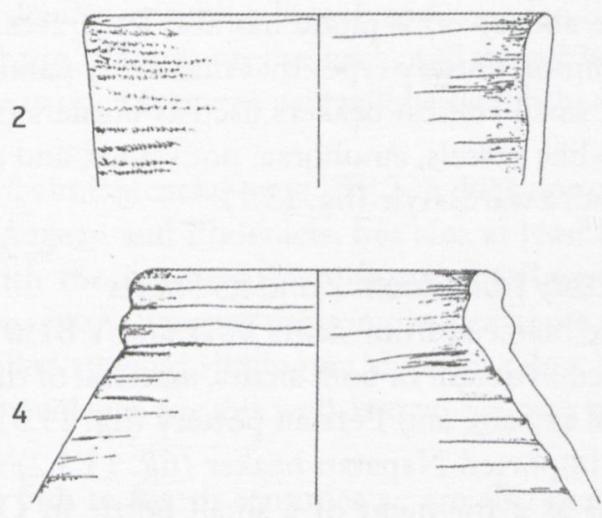

6

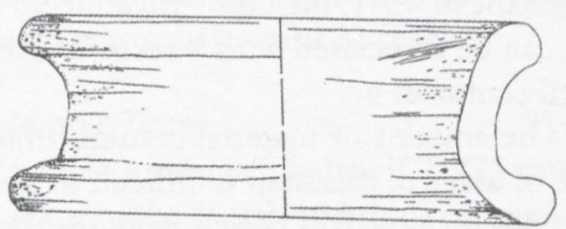

Fig. 13.5. Selected pottery from V.A1 and V.B1 of TT 223 (scale 1:3). Drawing Julia Budka

\section{Pottery from the First Pillared Hall}

The second focus of work on the ceramic material from TT 223 was on the pottery unearthed during the excavation of the First Pillared Hall. Here, the so-called bone layer (see Ikram, Chapter 14, in this volume) was of special interest. Although the material from this deposit is of very mixed character-comprising few New Kingdom sherds, some Late Period vessels, but mostly Ptolemaic, Roman, and Coptic, as well as Islamic, material - a preliminary dating of the level 0-20 centimeters above the floor seems possible. Despite random Coptic pieces, these deposits mainly originate from early to mid-Ptolemaic times. Interestingly, much of this material of third- to up to second-century вс date was secondarily burnt and/or covered with resin/bitumen. In general, the most common types are small offering plates, dishes, and cups and beakers used as burners, as well as embalming cups (sometimes with hieratic dockets) ${ }^{29}$ and carinated bowls of various sizes and types (fig. 13.6). ${ }^{30}$ Closed forms include socalled oil jars (fig. 13.8) and small jugs, as well as painted amphorae (fig. 13.7).

The frequent presence of oil and resin residues is paralleled in contemporary pottery excavated in the Northern Asasif ${ }^{31}$ and elsewhere in Thebes. ${ }^{32}$ It is difficult to assess the function of the vessels, especially of the large so-called oil jars (see fig. 13.8) 3 $^{33}$ dating to the early Ptolemaic period. Partly related to canopic jars, they also resemble aspects of ritual vessels, ${ }^{34}$ as well as common burial jars related to the storage of commodities. ${ }^{35}$ In closed pottery shapes, remains of resin might be associated with mummification. Various oily substances were 

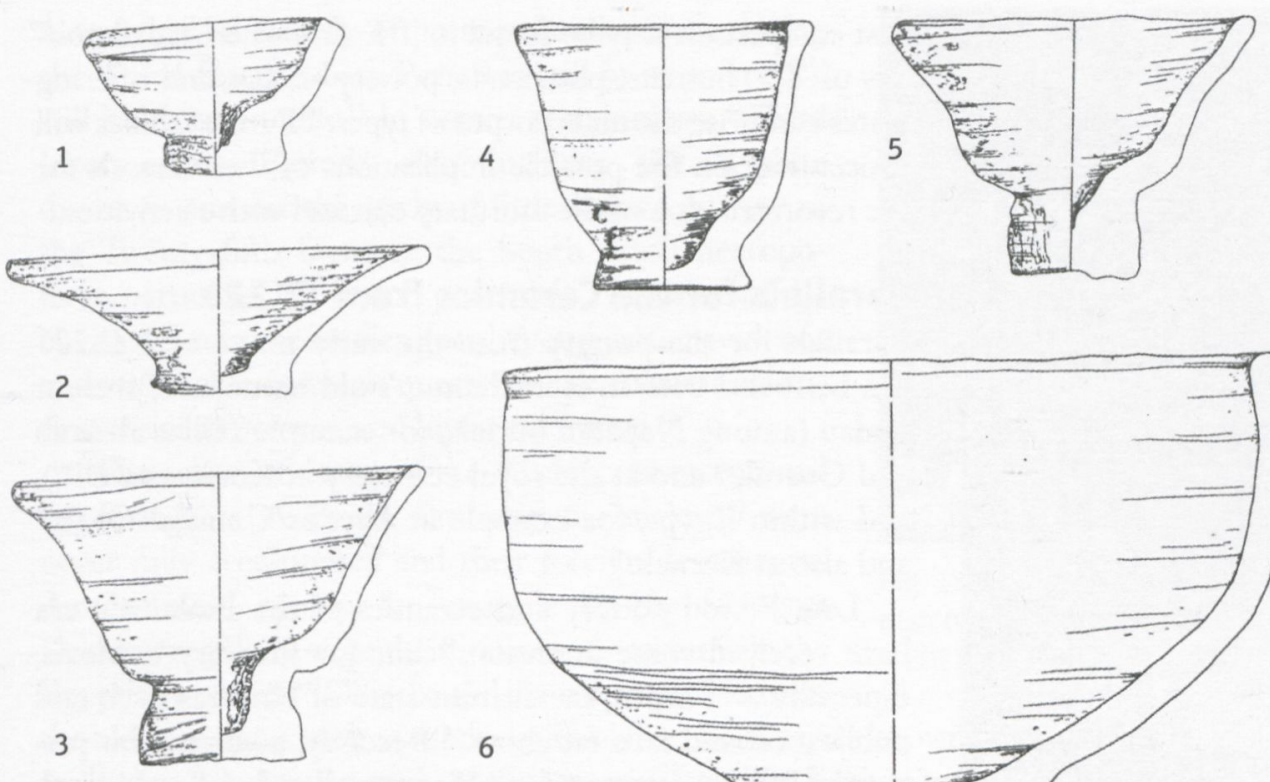

6

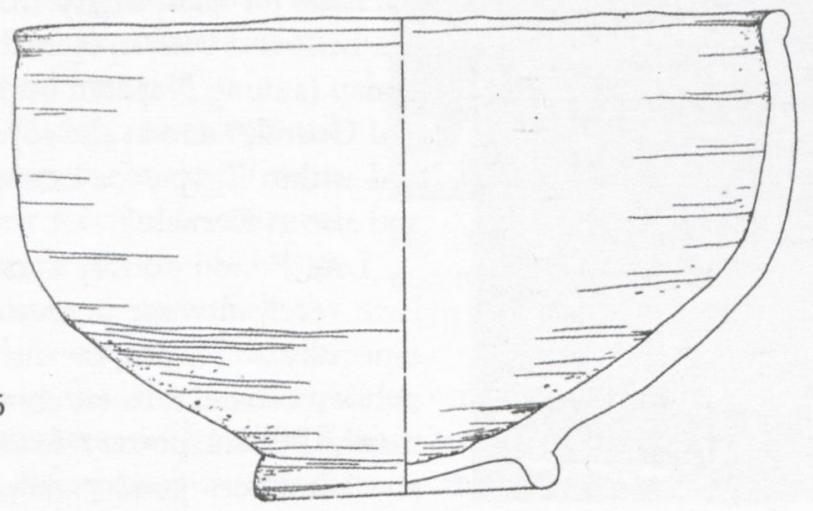

Fig. 13.6. Selected Ptolemaic pottery from the First Pillared Hall of TT 223 (scale 1:3). Drawing Julia Budka

used during mummification and during ritual acts performed on the mummy and other items of the burial equipment.

All in all, the material from the lowest level in the First Pillared Hall of TT 223 finds many parallels in the ceramics recovered from the same level in the pillared hall of TT $414 .{ }^{36}$ As can be clearly established for TT 414, these ceramics of Ptolemaic date can be associated with burials and especially with the respective mortuary cult. ${ }^{37}$

Late Ptolemaic material includes a considerable number of cooking pots and jars, which show traces of burning and might be associated with domestic activities. Domestic use of TT 223 is clearly attested for the late Roman and Coptic periods, as well as Islamic times (fig. 13.9). Amphorae, sieve vessels, cooking pots, bowls, and dishes underline the then-established dwelling character of the site.

\section{Pottery from the Open Courtyard}

Recent excavations in the open courtyard of TT 223, in its northwestern corner (I.4) have yielded some pottery of very mixed character. Some pieces from the New Kingdom are present, as well as a number from the Late Period (including storage jars of Twentyfifth Dynasty date) and Ptolemaic times. Most of the material is Roman and Coptic in date; a proportion is modern material of recent times. Despite this mix of materials, it is interesting to stress the fact that the Ptolemaic pieces are completely consistent with what we know from other open courtyards of Late Period temple tombs. The 


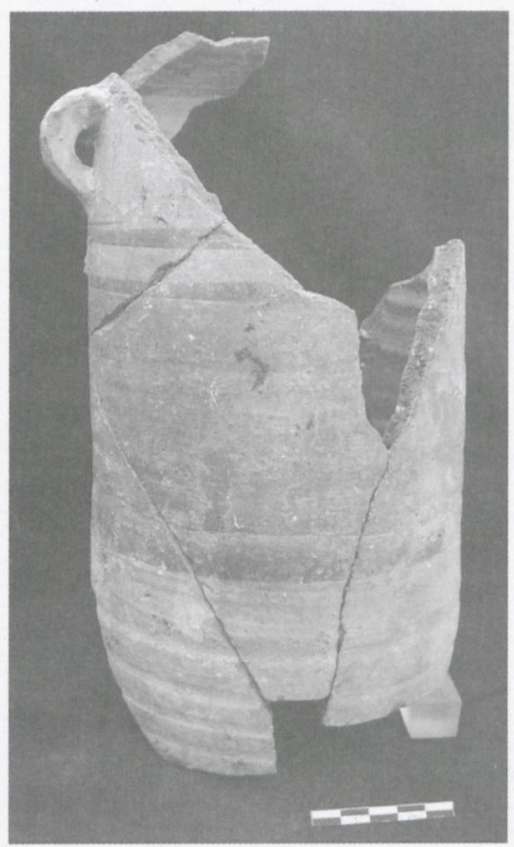

Fig. 13.7. Painted Ptolemaic amphora from TT 223 (Reg. No. P 2011.119). Photo Julia Budka

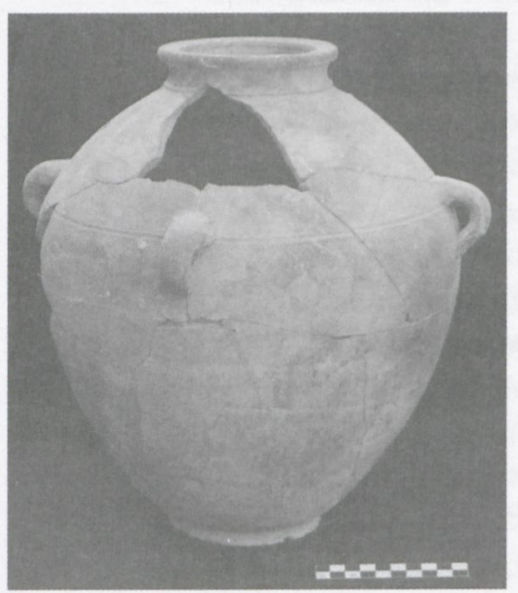

Fig. 13.8. Ptolemaic oil jar from TT 223 (Reg. No. P 2011.87). Photo Julia Budka best comparison may be found in TT 414, where small goblets used as burners, pot stands, pottery situlae, and offering plates comprise the main corpus of types. ${ }^{38}$ Future studies will concentrate on the possible implications of these vessels for the reconstruction of the mortuary cult and votive activities.

\section{Parallels for the Ceramics from TT $\mathbf{2 2 3}$}

Parallels for the pottery from the early phase of TT 223 can be found both in Karakhamun's old homeland, present Sudan (among Napatan burials, for example Hillat al-Arab and Qustul,,$^{39}$ and at the royal cemetery at Kurru as well ${ }^{40}$ ), and within Egypt, for example at Abydos/Umm al-Qaab ${ }^{41}$ and also at Karnak. ${ }^{42}$

Late Period pottery and ceramics of the Ptolemaic era have received some attention, ${ }^{43}$ but for funerary contexts, especially at Thebes, the current state of both research and publication still falls far short. ${ }^{44}$ Recently, a volume on primarily Persian pottery from Saqqara has been published, providing very good parallels for TT $223 .{ }^{45}$ Pottery from Late Period and Ptolemaic contexts at Karnak did receive new attention from A. Masson ${ }^{46}$ - thanks to her publications, new comparisons with this very similar material are possible.

In recent years, the later reuse of Kushite and Saite temple tombs in the Thirtieth Dynasty and Ptolemaic times has been addressed, in particular for TT $414^{47}$ and TT $37 .{ }^{48}$ Finally, G. Schreiber has presented a concise study of the so-called Ptolemaic Egyptian 'Hadra ware ${ }^{\text {'49 }}$ and also a short and very useful summary of Ptolemaic funerary culture at Thebes, including references to the most important pottery types. ${ }^{50}$

\section{Relevance of the Ceramics from TT 223}

The ceramics from the South Asasif necropolis and especially from TT 223 hold much potential, in two respects in particular: (1) the study of Kushite funerary culture at Thebes, and (2) the reconstruction of mortuary, ritual, and votive activities in Theban temple tombs in a diachronic perspective, including the phases of later reuse during Ptolemaic times.

Regarding (1): Despite recent achievements in the study of Egyptian ceramics originating from the Third Intermediate Period and the Late Period, there is still a "lack of well dated material." ${ }^{51}$ Recent archaeological fieldwork at sites like Thebes and Abydos has produced essential material from the Third Intermediate Period up to Ptolemaic times, but the assessment by 
Aston that "the study of pottery development during the Third Intermediate Period is still in its infancy" 52 still holds true today. ${ }^{53}$ In Aston's terminology, "Third Intermediate Period" also includes the Kushite dynasty - and for the study of little-known pottery of the Twenty-fifth Dynasty, the South Asasif necropolis in particular holds rich potential. The value of the envisaged ceramic studies goes beyond dating evidence and will tackle research questions like cultural identities, social structures, and historical events.

The self-confidence of the Kushites is exceptional for foreigners in Egypt. Probably the majority were never fully acculturated and their foreign descent was demonstrated openly, for example by the fact that Kushites regularly wore their indigenous costume in the Egyptian context. ${ }^{54}$ Objects of daily use imported from

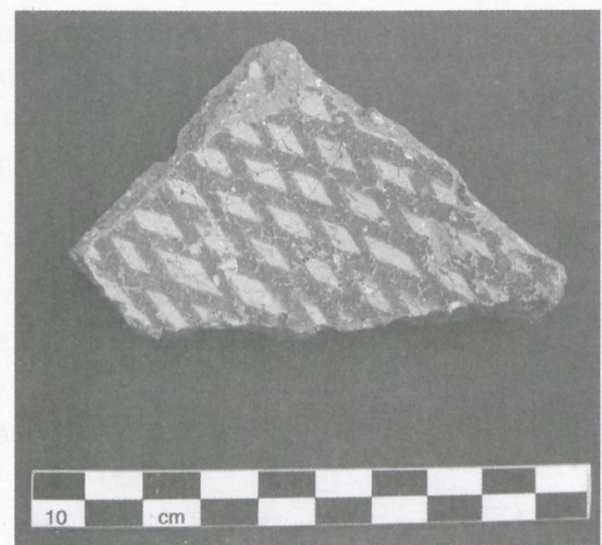

Fig. 13.9. Fragment of an Islamic decorated dish (view of interior) from TT 223 (Reg. No. P 2011.13). Photo Julia Budka the old homeland, such as drinking vessels and beakers, are known from Kushite burials at Thebes. ${ }^{55}$ A detailed study of the ceramics from the Kushite tombs in South Asasif as relevant remains of a significant material culture therefore has the potential to enlarge not only our knowledge of pottery of the Twenty-fifth Dynasty at Thebes, but also of Kushite self-confidence, material culture, and representation in Egypt in general.

Regarding (2): In general, pottery from Egyptian burial places attests to interments and other functional uses of tombs. Pottery may confirm ritual acts such as burning incense and other offerings related to burials and funerary rites. The high concentration of votive cups, bowls, and incense burners from TT 223, mostly of Thirtieth Dynasty and Ptolemaic date, finds good parallels in the tombs of Harwa (TT 37) and Ankh-Hor (TT 414). Mortuary cult within Theban temple tombs seems to have had a complex development, resulting in a temple-like offering cult in Ptolemaic times. ${ }^{56}$ The material from TT 223 adds further evidence in this respect and will contribute to the discussion of changes and continuity in the Theban pottery tradition from the Late Period to the Ptolemaic era. ${ }^{57}$

\section{Conclusive Remarks}

The pottery corpus from TT 223 illustrates the use-life of this tomb monumentits use includes a repeated function as burial place, initially in the Twenty-fifth Dynasty and repeated in the time span covering the period of the Twenty-sixth Dynasty until Ptolemaic times. It is still unclear whether the pottery datable to the Twenty-seventh Dynasty refers to Persian burials or just an embalming cache of this period. An increase in reuse as a tomb can be attested for the fourth century-in addition to the rich ceramic evidence, there are various coffins, chests, and other objects of this period. This reuse continues into the Ptolemaic period. The later phases (late Roman, Coptic, and Islamic) seem to refer to a domestic use of TT 223. 
Table 13.3: Detailed information on illustrated ceramics from TT 223.

\begin{tabular}{|c|c|c|c|c|c|}
\hline Fig. & Reg. No. P & Label/Form & Ware* & Dating & Find position \\
\hline Fig. 13.1.1 & 2011.58.2 & Beaker/Globular jar & Nile B3RW & 25th Dynasty & $X(1)$ \\
\hline Fig. 13.1.2 & 2011.58.3 & Globular jar & Nile B3RW & 25th Dynasty & $\mathrm{X}(1)$ \\
\hline Fig. 13.1.3 & 2011.19 & Cup/goblet & Nile B3UC & 25th Dynasty & $X(1)$ \\
\hline Fig. 13.1.4 & 2011.63 & Storage vessel & Marl A4UC & $\begin{array}{l}25 \text { th (to 26th) } \\
\text { Dynasty }\end{array}$ & $X(1), X(3)$ \\
\hline Fig. 13.2.1 & 2011.77 & Goldfish bowl & Nile B3RW & 5th-4th century & $\mathrm{XA}, \mathrm{X}(1)-(4)$ \\
\hline Fig. 13.2.2 & 2011.146 & Handled dish & Marl A2/4UC & 5th-4th century & $X(1), X(2)$ \\
\hline Fig. 13.2.3 & 2011.1 & Oasis keg & $\begin{array}{l}\text { Oasis B23/ } \\
\text { Dakhla (Hope) }\end{array}$ & 26th-27th Dynasties & $X(4)$ \\
\hline Fig. 13.2.4 & 2011.129 & Storage vessel & Marl A4UC & 26th-27th Dynasties & XA, X (1), IX.6 \\
\hline Fig. 13.2.5 & 2011.70 & Necked slender jar & Nile D3RW & 27th Dynasty? & XA, shaft, X (1)-(4) \\
\hline Fig. 13.3.1 & 2011.137 & Sausage jar & $\begin{array}{l}\text { Nile C3WW' } \\
\text { UC }\end{array}$ & $\begin{array}{l}\text { 4th century? } \\
\text { Ptolemaic? }\end{array}$ & $\begin{array}{l}\text { IV.N6, } 15-20 \mathrm{~cm} \\
\text { above floor }\end{array}$ \\
\hline Fig. 13.3.2 & 2011.117.1 & Necked jar & Nile B3RB & 5 th century & $X(1)-(4)$ \\
\hline Fig. 13.4.1 & 2011.62 & Carinated dish/bowl & Nile B3UC & Ptolemaic & IX.1+2 \\
\hline Fig. 13.4.2 & 2011.43 & Cup/beaker & Nile C3UC & Ptolemaic & IX.6 \\
\hline Fig. 13.5.1 & 2011.27 & Beaker & Marl A4UC & 25th Dynasty & V.B1 \\
\hline Fig. 13.5.2 & 2011.26 .2 & Napatan beaker & Nile B3varRB & 25th Dynasty & V.B1 \\
\hline Fig. 13.5.3 & 2011.7.1 & Cup/goblet & Nile B3UC & 25th Dynasty & $\begin{array}{l}\text { V between S6 and } \\
\text { S7, near floor level }\end{array}$ \\
\hline Fig. 13.5.4 & 2011.34 .3 & Storage vessel & Marl A4UC & 26th Dynasty & V.B1 \\
\hline Fig. 13.5.5 & 2011.10.2 & Pot stand & Nile C3UC & Ptolemaic & V.A1 \\
\hline Fig. 13.5.6 & 2011.10.1 & Pot stand & Nile B3UC & Ptolemaic & V.A1 \\
\hline Fig. 13.6.1 & 2011.81 & $\begin{array}{l}\text { Dish/lid/miniature } \\
\text { vessel }\end{array}$ & Nile C3UC & Ptolemaic & $\begin{array}{l}\text { IV.N6, } 15-20 \mathrm{~cm} \\
\text { above floor }\end{array}$ \\
\hline Fig. 13.6.2 & 2011.94 & $\begin{array}{l}\mathrm{Dish} / \text { miniature } \\
\text { vessel }\end{array}$ & Nile B3UC & Ptolemaic & IV.SP4 \\
\hline Fig. 13.6.3 & 2011.79 & Cup/beaker & Nile C3UC & Ptolemaic & $\begin{array}{l}\text { IV.N6, 15-20 cm } \\
\text { above floor }\end{array}$ \\
\hline Fig. 13.6.4 & 2011.82 & $\begin{array}{l}\text { Embalming pot/ } \\
\text { beaker }\end{array}$ & Nile B3UC & Ptolemaic & $\begin{array}{l}\text { IV.C4, } 50-200 \mathrm{~cm} \\
\text { above floor }\end{array}$ \\
\hline Fig. 13.6.5 & 2011.61 & Cup/beaker & Nile B3UC & Ptolemaic & IV.SP3 \\
\hline Fig. 13.6.6 & 2011.99 & Bowl & Nile B3RW & Ptolemaic & IV.C6, 0-50 cm \\
\hline Fig. 13.7 & 2011.119 & $\begin{array}{l}\text { Storage vessel/ } \\
\text { Amphora }\end{array}$ & Nile C3WWBI & 4th to 3 rd centuries & $\begin{array}{l}\text { IV.S } 5.1+5.2,5.2 \\
\text { SW }\end{array}$ \\
\hline Fig. 13.8 & 2011.87 & Oil jar & K200RW & Ptolemaic & $\begin{array}{l}\text { IV.N6, } 15-20 \mathrm{~cm} \\
\text { above floor }\end{array}$ \\
\hline Fig. 13.9 & 2011.13 & Plate/dish & $\begin{array}{l}\text { Nile/Mix I-g, } \\
\text { WWMO } \\
\text { painted }\end{array}$ & Islamic & $\begin{array}{l}\text { IV. S. } 8,50 \mathrm{~cm} \text { from } \\
\text { floor }\end{array}$ \\
\hline
\end{tabular}

* The following abbreviations are used for the surface treatment: RW = red washed; UC = uncoated; $\mathrm{WW}=$ white washed; $\mathrm{RB}=$ red burnished; $\mathrm{WWBI}=$ white washed, bichrome painted, $\mathrm{WWMO}=$ white washed, monochrome painted. 
Finally, a number of remains of modern pottery reveal aspects of the recent history of the tomb of Karakhamun in connection with the Abd el Rasul family.

Future research will concentrate on a detailed study of the pottery from TT 223 datable to the Twenty-fifth Dynasty and will focus on the question of Kushite indigenous pottery at Thebes. Comparing the material from TT 223 with ceramics from both Abydos and present Sudan, ritual connections between Abydos, Thebes, and al-Kurru will be reviewed by means of the ceramic evidence. ${ }^{58}$ Another focus of interest for the next season is pottery associated with the Twenty-seventh Dynasty - the embalming cache will be completely studied. Finally, several questions are still open concerning the functional use of TT 223 in Ptolemaic times, especially in the area of the First Pillared Hall-the pottery analysis will contribute to this research as well (table 13.3).

\section{Notes}

1 Julia Budka, "Neues zu den Nutzungsphasen des Monumentalgrabes von Anch-Hor, Obersthofmeister der Gottesgemahlin Nitokris (TT 414)," Ägypten und Levante 18 (2008): 61-85; Julia Budka, Bestattungsbrauchtum und Friedhofsstruktur im Asasif. Eine Untersuchung der spätzeitlichen Befunde anband der Ergebnisse der österreichischen Ausgrabungen in den fabren 1969-1977, Untersuchungen der Zweigstelle Kairo 34 (Vienna: Verl. der Öster. Akad. der Wiss., 2010), 82-84.

2 Budka, Bestattungsbrauchtum und Friedhofsstruktur, 222-24, 360-62, fig. 148; Julia Budka, "The Use of Pottery in Funerary Contexts during the Libyan and Late Period: A View from Thebes and Abydos," in Egypt in Transition: Social and Religious Development of Egypt in the First Millenium BCE, edited by Ladislav Bareš et al. (Prague: Charles University in Prague, 2010), 37-46.

3 See Budka, Bestattungsbrauchtum und Friedhofsstruktur, 356-58, for further references.

4 Budka, Bestattungsbrauchtum und Friedbofsstruktur, 193-208.

5 For this late occurance of Nile D, compare David A. Aston, Burial Assemblages of Dynasty 21-25: Cbronology—Typology—Developments, Contributions to the Chronology of the Eastern Mediterranean 21, Öster. Akad. der Wiss., Denkschriften der Gesamtakademie 54 (Vienna: Verl. der Öster. Akad. der Wiss., 2009), 320. For this type of tall-necked jar, usually red slipped, see Aurélia Masson, "Persian and Ptolemaic Ceramics from Karnak: Change and Continuity," Cabiers de la Céramique Égyptienne 9 (2011): 275, fig. 41.

6 David A. Aston and Barbara G. Aston, Late Period Pottery from the New Kingdom Necropolis at Saqqâra, Egypt Exploration Society-National Museum of Antiquities, Leiden, Excavations 1975-1995, Excavation Memoir 92 (London, Leiden: The Egypt Exploration Society, 2010), 3.

7 Budka, Bestattungsbrauchtum und Friedhofsstruktur, 202-203.

8 Compare Aston, Burial Assemblages, 320-21.

9 See Budka, Bestattungsbrauchtum und Friedbofsstruktur, 200, with references.

10 Colin Hope, "Kegs and Flasks from the Dakhleh Oasis," Cabiers de la Céramique Égyptienne 6 (2000): 195; compare also Aston, Burial Assemblages, 321.

11 For comparison with similar finds from the Northern Asasif, see Budka, Bestattungsbraucbtum und Friedbofsstruktur, 424-26 (with further references on Aegean amphorae in Late Period Egypt). 
12 For good parallels from Karnak, see Masson, "Persian and Ptolemaic Ceramics from Karnak," 310, figs. 114-16.

13 For functional aspects of funerary pottery, in particular overlapping boundaries between burial pottery and cultic vessels, see Budka, "The Use of Pottery in Funerary Contexts."

14 Referring to Aston's typology as published in Aston, Burial Assemblages, 321-48.

15 Uvo Hölscher, The Excavations of Medinet Habu. Vol. 5: The Post-Ramesside Remains, Oriental Institute Publications 66 (Chicago: University of Chicago, 1954), 74 and pl. 47, X 4; Aston, Burial Assemblages, 322, fig. 21:40.

16 Bruce B. Williams, Twenty-fifth Dynasty and Napatan Remains at Qustul: Cemeteries W and $V$, Oriental Institute Nubian Expedition Vol. 7 (Chicago: University of Chicago Press, 1990), 8, group IV, note a with references, figs. 2b and 21b; see also Budka, Bestattungsbrauchtum und Friedhofsstruktur, 345-46, fig. 141.

17 Budka, Bestattungsbrauchtum und Friedhofsstruktur, 345-46; Julia Budka, "Kushite Tomb Groups in Late Period Thebes," in Proceedings of the 11th International Conference of Nubian Studies, Warsaw University, 27 August-2 September 2006, Part Two: Session Papers, edited by Włodzimierz Godlewski and Adam Łajtar, Polish Archaeology in the Mediterranean Supplement Series 2.2/2, Polish Centre of Mediterranean Archaeology, University of Warsaw (Warsaw: Warsaw University Press, 2010), 507, fig. 3.

18 For general dating problems concerning Persian funerary remains, see David A. Aston, "Dynasty 26, Dynasty 30 or Dynasty 27? In Search of the Funerary Archaeology of the Persian Period," in Studies in Ancient Egypt in Honour of H.S. Smith, edited by Anthony Leahy and John Tait (London: The Egypt Exploration Society, 1999), 17-22.

19 See, most recently, Aston and Aston, Late Period Pottery, 27-59.

20 For different types of embalming deposits in Late Period Thebes, see Budka, "Deponierungen von Balsamierungsmaterial im spätzeitlichen Theben (Ägypten). Befund, Kontext und Versuch einer Deutung," in Arcbäologie und Ritual. Auf der Suche nach der rituellen Handlung in den antiken Kulturen Ägyptens und Griechenlands, edited by Jannis Mylonopoulos and Hubert Roeder (Vienna: Phoibos, 2006), 85-103; and Budka, Bestattungsbrauchtum und Friedhofsstruktur, 433-50.

21 Phonician amphorae (compare Elizabeth A. Bettles, Phoenician Amphora Production and Distribution in the Southern Levant: A Multi-Disciplinary Investigation into Carinated-Shoulder Amphorae of the Persian Period (539-332 BC), BAR International Series 1183, Oxford: British Archaeological Reports, 2003), which are very common throughout the Levant, are often found in Egyptian embalming deposits (compare Budka, Bestattungsbrauchtum und Friedhofsstruktur, 449; see also Aston and Aston, Late Period Pottery, 104-105).

22 Aston and Aston, Late Period Pottery, 48, nos. 105 and 107.

23 Budka, Bestattungsbrauchtum und Friedbofsstruktur, 220-22, figs. 86-87.

24 Masson, "Persian and Ptolemaic Ceramics from Karnak," 274 with note 36, figs. 29 and 34.

25 For example, Budka, Bestattungsbrauchtum und Friedhofsstruktur, 403; Gábor Schreiber, "Early and Middle Ptolemaic Funerary Art at Thebes (ca. 306-88 BC)," in Proceedings of the Colloquium on Theban Archaeology at the Supreme Council of Antiquities, edited by Zahi Hawass et al. (Cairo: Supreme Council of Antiquities, 2011), 112, fig. 10.

26 For example, Budka, Bestattungsbrauchtum und Friedhofsstruktur, 230-33, with further references, figs. 96-97. 
27 Many parallels of this slender bottle shape are known from Abydos/Umm al-Qaab, see David A. Aston, "A Group of Twenty-Fifth Dynasty Pots from Abydos," MDAIK 52 (1996): fig. 3e; a similar Oasis bottle was recently found in the Mut precinct of Karnak, see Elaine Sullivan, "A Report on the Third Intermediate Period and Late Period Pottery from the Mut Temple, Luxor," Cabiers de la Céramique Égyptienne 9 (2011): 550, fig. 21.

28 The evidence for the Twenty-fifth Dynasty is restricted to three small rim sherds and a base of a goblet, which might eventually also prove to be intrusive/mixed from other areas of the tomb; the material of the Twenty-sixth Dynasty comprises several fragments of large storage vessels and other types, more likely to be associated with a burial.

29 Compare Budka, Bestattungsbraucbtum und Friedhofsstruktur, 420, fig. 172.

30 These find many parallels in the Northern Asasif (Budka, Bestattungsbraucbtum und Friedhofsstruktur, figs. 93, 197, 231 (Reg. 352g) and 241 (K92.9)) and Karnak (Masson, "Persian and Ptolemaic Ceramics from Karnak," 302, figs. 68-75).

31 Budka, "The Use of Pottery in Funerary Contexts," 22-72; and Budka, Bestattungsbrauchtum und Friedhofsstruktur, 380.

32 Schreiber, "Early and Middle Ptolemaic Funerary Art," 124, fig. 33.

33 Gábor Schreiber, "The Final Acts of Embalming: An Archaeological Note on Some Rare Objects in Theban Elite Burials of the Early Ptolemaic Period," in Proceedings of the Fourth Central European Conference of Young Egyptologists, 31 August-2 September, 2006, Budapest, edited by Kata Endreffy and András Gulyás, Studia Aegyptiaca 18 (Budapest: ELTE Régészeti Tanszek, 2007), 342; Schreiber, "Early and Middle Ptolemaic Funerary Art," 124.

34 Schreiber, "The Final Acts of Embalming," 342; Budka, "The Use of Pottery in Funerary Contexts," 29.

35 Budka, Bestattungsbrauchtum und Friedhofsstruktur, 378.

36 Manfred Bietak and Elfriede Reiser-Haslauer, Das Grab des Anch-Hor. Obersthofmeister der Gottesgemablin Nitokris, 2. Untersuchungen der Zweigstelle Kairo des Österreichischen Archaeologischen Institute 5 (Vienna: Öster. Akad. der Wiss., 1982), 153-59, fig. 65; Budka, "The Use of Pottery in Funerary Contexts," 38-46.

37 Compare Budka, "Neues zu den Nutzungsphasen," 79-80; Julia Budka, "Varianz im Regelwerk. Bestattungsabläufe im Monumentalgrab von Anch-Hor, Obersthofmeister der Gottesgemahlin Nitokris (TT 414)," Ägypten und Levante 20 (2010): 59-63.

38 Compare Budka, "The Use of Pottery in Funerary Contexts," 37-46.

39 See Irene Vincetelli, Hillat el-Arab, the foint Sudanese-Italian Expedition in the Napatan Region, Sudan, BAR International Series 1570, Sudan Archaeological Research Society Publication 15 (Oxford, London: British Archaeological Reports, 2006), passim; Williams, Twenty-Fifth Dynasty and Napatan Remains at Qustul, passim.

40 Compare Lisa Heidorn, "Historical Implications of the Pottery from the Earliest Tombs at El Kurru," FARCE 31 (1994): 115-31; Julia Budka, "Egyptian Impact on Pot-breaking Ceremonies at Kurru? A Re-examination," in Proceedings of the 12th International Conference for Nubian Studies, British Museum London, 1st August-6th August 2010, edited by Derek A. Welsby and Julie R. Anderson (in press).

41 Budka, "The Use of Pottery in Funerary Contexts," 55-58.

42 Sullivan, “A Report," figs. 21, 28-30, 40, 49-50. 
43 For example, David A. Aston, Elephantine XIX, Pottery from the Late New Kingdom to the Early Ptolemaic Period, AVDAIK 95 (Mainz am Rhein: Philipp von Zabern, 1999), passim; David A. Aston, "Amphorae, Storage Jars and Kegs from Elephantine: A Brief Survey of Vessels from the Eighth-Seventh Centuries BC to the Seventh-Eighth Centuries AD," in Amphores d'Égypte de la Basse Époque à l'époque arabe 2, edited by Sylvie Marchand and Antigone Marangou (Cairo: Institut Français d'Archéologie Orientale, 2007), 419-44; Masson, "Persian and Ptolemaic Ceramics from Karnak," 269-310.

44 For two volumes presenting ceramics from Late Period temple tombs, see Erhart Graefe, Das Grab des Padihorresnet, Obervermögensverwalter der Gottesgemablin des Amun (Thebanisches Grab Nr. 196), Monumenta Aegyptiaca 9 (Tournhout: Brepols; Brussels: Fondation Égyptologique Reine Élisabeth, 2003); Budka, Bestattungsbraucbtum und Friedhofsstruktur.

45 Aston and Aston, Late Period Pottery, passim.

46 Masson, "Persian and Ptolemaic Ceramics from Karnak," 269-310, with further references.

47 Budka, "Neues zu den Nutzungsphasen," and "The Use of Pottery in Funerary Contexts."

48 Sabine Laemmel, "A Pottery Assemblage from the Tomb of Harwa (Western Thebes): Mortuary and Cultic Reuse of a 25th Dynasty Funerary Structure," in Functional Aspects of Egyptian Ceramics in their Archaeological Context. Proceedings of a Conference beld at the McDonald Institute for Archaeological Research, Cambridge, Fuly 24th-7uly 25th, 2009, edited by Bettina Bader and Mary Ownby, Orientalia Lovaniensia Analecta 217 (Leuven: Peeters, 2012), 3, 217-47.

49 Gábor Schreiber, Late Dynastic and Ptolemaic Painted Pottery from Thebes (4th-2nd c. BC), Dissertationes Pannonicae Ser. 3, Vol. 6 (Budapest: ELTE Régészeti Tanszek, 2003), passim.

50 Schreiber, "Early and Middle Ptolemaic Funerary Art," 105-39.

51 Aston, Egyptian Pottery of the Late New Kingdom and Third Intermediate Period, SAGA 13 (Heidelberg: Heidelberger Orientverlag, 1996), 15.

52 Aston, Burial Assemblages, 317.

53 Budka, "The Use of Pottery in Funerary Contexts," 22.

54 Cf. Angelika Lohwasser, "Fremde Heimat. Selektive Akkulturation in Kusch," in Timelines: Studies in Honour of Manfred Bietak 3, edited by Ernst Czerny, Irmgard Hein, Hermann Hunger, Dagmar Melman, and Angela Schwab (Orientalia Lovaniensia Analecta 149.3, Leuven: Peeters, 20), 136; Budka, "Kushite Tomb Groups," 503-18, Budka, "Individuen, indigene Gruppe oder integrierter Teil der ägyptischen Gesellschaft? Zur soziologischen Aussagekraft materieller Hinterlassenschaften von Kuschiten im spätzeitlichen Ägypten,” in Sozialisationen: Individuum - GruppeGesellschaft, Beiträge des ersten Münchner Arbeitskreises funge Aegyptologie (MA7A 1), 3. bis 5.12. 2010, edited by Gregor Neunert et al., Göttinger Orientforschungen Reihe IV, vol. 51 (Wiesbaden: Harrassowitz, 2012), 45-60.

55 Compare Budka, "Kushite Tomb Groups," 514.

56 Budka, "The Use of Pottery in Funerary Contexts," 62-64.

57 Compare Masson, "Persian and Ptolemaic Ceramics from Karnak," 269-310.

58 Budka, "Egyptian Impact on Pot-breaking Ceremonies." 